\title{
Undoing the Double-Cross: Promoting Public Accountability in American Science Agencies
}

\author{
Patrick Buckley ${ }^{*}$, Kristen Ramsey*
}

Yale University, Department of Microbial Pathogenesis, New Haven, CT

${ }^{*}$ Authors contributed equally

https://doi.org/10.38126/ISPG180301

Corresponding author: buckleympatrick@gmail.com

Keywords: Science, The Endless Frontier; Vannevar Bush; Harley Kilgore; public accountability; citizen input; National Science Board; National Science Foundation

Executive Summary: The leadership and advisory boards of American science agencies are largely organized according to the ideas set forth by an influential scientist, Dr. Vannevar Bush, after World War II. Although American science agencies are publicly funded, only experts control what research is funded and how each agency operates. Wielding his unique position of power after the war, Dr. Vannevar Bush suppressed the ideas of his adversary, Senator Harley Kilgore, resulting in the absence of public accountability and citizen input that defines American science agencies today. We argue that citizens must have a seat at the table in the leadership of science agencies to promote trust in science, reduce inequity, increase efficiency, embrace democratic principles, and address the needs of the American people. By providing a mechanism for non-expert citizens to influence the direction of American science agencies, Congress can now finally rectify the double-cross of Senator Harley Kilgore by Dr. Vannevar Bush.

\section{The exclusive frontier}

Science is intimately connected to the government in the United States. During World War II, American scientists working on behalf of the U.S. government shocked the nation and the world with the creation of the first atomic bomb. Not long after WWII, publicfacing programs such as NASA began to awe generations of Americans. For the public, the response to the COVID-19 pandemic is another example of the supportive relationship between the federal government and science. Notably, Operation Warp Speed has become a household name and represents an extraordinary collaboration between scientists, industry, and the federal government (Slaoui and Hepburn 2020).

Although it appears that American science is held accountable to the public through its deep connection with the U.S. government, scientists are in almost complete control of publicly funded research programs. Scientists alone determine what proposed research is funded and are not required to ensure that research is directly relevant to any public need.
Without input from non-expert citizens, the vast majority of funding for research is distributed by panels of scientists who review and decide what research proposals to fund.

Today's structure of research funding, where scientists review and approve the distribution of money for other scientists' proposed research, can be attributed to Dr. Vannevar Bush. As President Franklin D. Roosevelt's science advisor during WWII, Dr. Bush proposed a new vision for American science that proved to be tremendously influential. In Dr. Bush's 1945 report, Science, The Endless Frontier, he asserted that, "Scientific progress on a broad front results from the free play of free intellects, working on subjects of their own choice, in the manner dictated by their curiosity for exploration of the unknown." This notion that scientific progress results from the "free play of free intellects" is so ingrained in the structure of modern-day American science that the idea is now unremarkable. Similarly, the story behind Dr. Bush's influence is rarely questioned. 
The United States must ask if Dr. Bush's decades-old arrangement, which sacrifices citizen input for scientific independence, is sustainable. By forcibly disconnecting the public from the scientific agencies they fund, scientific independence from public accountability has damaged both science and the public. Scientific independence has promoted the mistrust of science, perpetuated inequity in science, sacrificed improved efficiency, shunned democratic principles, and prevented science from more effectively addressing the needs of the citizens who fund research. We argue that a stylistic shift is needed in America's science agencies. By including members of the public in their leadership, American science will become more effective and more inclusive. To move forward, we must first understand how the U.S. came to accept such broad scientific independence from citizen input. After understanding the origins of scientific independence, the benefits of citizen input become clear.

\section{The WWII origins of scientific independence}

Science has played an increasingly important role in the United States throughout its history, eventually reaching a pivotal moment during WWII. One of the first sustained relationships between the federal government and scientific research was in agriculture. In 1862, the Department of Agriculture issued its first Research Bulletin on the sugar content of grape varieties for winemaking and has continued its research efforts to this day (U.S. Department of Agriculture 2019). Rapid technological progress during the early twentieth century led to several other formalized relationships between the federal government and research. Soon after the invention of the airplane, the National Advisory Committee on Aeronautics (NACA) was created to direct research and development on the newly emerging technology (Anderson 1981, 2). The need for wartime research that produced useful technology during WWII provided a final impetus to solidify federal support of research.

Before the U.S. joined WWII, President Roosevelt created the National Defense Research Committee (NDRC), which eventually became the Office of Scientific Research and Development (OSRD), to accelerate and centralize scientific research under the U.S. military (Zachary 1997, 112 and 129-130). Dr. Vannevar Bush, the former chairman of NACA, former chairman of NDRC, and later director of OSRD, played a huge role in various wartime research efforts like the Manhattan Project (Zachary 1997, 203). Reporting only to President Roosevelt, Dr. Bush had tremendous influence. In 1944, Dr. Vannevar Bush received a letter from the President requesting a report on how the national wartime research effort could be applied in peacetime. His response, titled Science, The Endless Frontier, would go on to lay the foundation of the American scientific enterprise that we still have today. This historical account, although commonly retold, omits a critical element-the story of a Senator from West Virginia named Harley Kilgore.

\section{The double-cross}

What do we miss when we fail to consider the perspective of Senator Kilgore? Most importantly, we remain unaware of how the U.S. traded citizen input for scientific independence. Dr. Bush's Science, The Endless Frontier laid the framework that would later lead to the formation of the National Science Foundation (NSF). Dr. Bush's proposal helped to legitimize federal financial support for curiositydriven research, the so-called "free play of free intellects", but notably did not incorporate public accountability. Dr. Bush, however, was not the only voice in the discussion on how to structure federally funded research.

In 1942, 1943, and 1945, Senator Harley Kilgore introduced legislation that would have created one federal agency to oversee all research funding and administration (Neal et al. 2008, 18). Although his 1942 and 1943 bills were aimed at mobilizing science and technology toward the war effort, his 1945 legislation (79 S. 1297) aimed to establish an independent agency to orchestrate peacetime research efforts. This bill would have established a National Science Foundation that differed from Dr. Bush's vision in dramatic ways. Some of the key differences in Senator Kilgore's plan included a Presidentially appointed director with a board composed of members of the public in addition to technical experts. The legislation also included funding for the social sciences that would be distributed geographically as opposed to a meritbased system. Although these are just a few key differences, it is clear from their proposals that Senator Kilgore and Dr. Bush saw two divergent futures for American science after the war. 
Despite their differences, Senator Kilgore invited Dr. Bush to help draft his 1945 peacetime legislation, even though Dr. Bush had opposed the Senator's 1942 and 1943 bills (Neal et al. 2008, 19). Dr. Bush, however, would again oppose the Senator's legislation. This was likely, at least in part, because a Presidentially appointed director and the inclusion of non-expert citizens on the board would not represent complete scientific independence. Opposed to the Senator's bill and holding considerable influence, Dr. Bush engaged in backdoor discussions with allies including President Roosevelt's own wordsmith and advisor, Samuel I. Rosenman (Kevles 1974, 800). In doing so, Dr. Bush helped to craft the fateful letter that was addressed to himself and signed by President Roosevelt, requesting a report on how to shift wartime research efforts toward peacetime.

Using his backdoor connection with President Roosevelt as an opportunity to formalize his own thoughts on how to structure a national science agency, Dr. Bush then asked Senator Kilgore to delay his legislation under the pretense of partnership (England 1976, 43). In the meantime, Dr. Bush finished his report, Science, The Endless Frontier, and worked with Senator Warren Magnuson to draft legislation (79 S. 1285) based on his own ideas and proposals. The Bush-Magnuson bill was introduced the same day Science, The Endless Frontier was released, showing that Dr. Bush's offer to collaborate with Senator Kilgore was disingenuous (Neal et al. 2008, 19). Thus, Dr. Bush completed his 'doublecross' of Senator Kilgore and sidestepped much of the potential deliberations and compromises that may have been necessary if he was sincere about cooperating on legislation.

\section{Moving beyond the double-cross}

Dr. Bush bypassed additional Congressional debate by double-crossing Senator Kilgore, depriving both scientists and the public of a more meaningful discussion about how to support American science post-WWII. By the time a bill to create a federal agency for 'basic,' curiosity-driven research passed both chambers of Congress, the debate over what level of scientific independence was appropriate in the agency had moved so far away from the original vision of Senator Kilgore that there was virtually no public accountability built into the administration of the NSF. In the 1947 version of the National Science Foundation Act (80 S. 526), no non-scientist citizens would sit on the board and the director would be chosen not by the President, but by the board. This plan, backed by Dr. Bush, was pocket-vetoed by President Harry Truman. Addressing Congress in 1947, President Truman cited the bill's lack of public accountability for his veto; he even went so far as to say that the legislation was, "divorced from control by the people to an extent that it implies a distinct lack of faith in democratic processes." Ultimately, the leadership structure of the NSF incorporated a small amount of public accountability, including Senator Kilgore's proposal to have a Presidentially appointed director.

While the President indirectly holds the current NSF accountable to the public, non-expert citizens are still unable to be appointed to the board (National Science Foundation n.d.). Although other U.S. science agencies have a wide variety of advisory board structures and membership requirements, a defining characteristic shared by all is their lack of mandatory non-expert membership (General Services Administration n.d.). Despite the fact that the original vision of Dr. Vannevar Bush was not fully realized, federally supported research in the U.S. is still much closer to his vision than perhaps that of any other individual. We believe that the most damaging result of Dr. Bush's double-cross is the lack of citizen input in U.S. science agencies that persists to this day. In order to see the drawbacks of scientific independence, the exclusionary structures that still exist must be examined.

\section{The structures currently in place}

Besides the National Science Foundation, U.S. science agencies are hindered by their lack of an advisory board that shares power with their agency's director. The NSF is led by both a director and the National Science Board (NSB), the latter of which establishes the policies of the NSF, identifies critical issues, and approves the agency's proposed budget (National Science Foundation n.d.). In contrast, the other major nondefense science funding agencies do not have an analogous group with the authority to manage the research activities of the organization (General Services Administration n.d.). For example, although the National Institutes of Health (NIH) has the Advisory Committee to the Director and the Council of Councils, they have no official power past providing advice and making recommendations to the NIH director (National Institutes of Health 2019; 
National Institutes of Health 2021). We believe that advisory boards with official power to manage their respective agencies along with their director are beneficial, due to the collective wisdom and perspective that they can bring to important decisions. Specifically, we argue that National Science Board-style advisory boards would be well-suited to guide other agency directors in the management of research-related activities.

The structure of U.S. science agencies also prevents citizens from influencing the direction of scientific research. Although some advisory board charters allow members of the general public to officially join, non-experts are rarely actually appointed and are vastly outnumbered in the boards where they are members (General Services Administration n.d.). This means that these agencies are, in practice, connected to the public only through the President of the United States, who has the power to appoint agency directors and in the case of the NSF, the members of the National Science Board. Therefore, in these current structures, the public must achieve the remarkably difficult goal of electing a President who shares their vision of American science in order to influence the direction of scientific research. Alternatively, Congress could alter the agency leadership structures to provide additional mechanisms for public feedback. Overall, it is clear that the structures in place make it extremely impractical for non-experts to make their voices heard when it comes to the scientific enterprise in the United States.

\section{Why include citizen input?}

The resistance to public accountability in federally funded research that can be originally attributed to Dr. Vannevar Bush is still a defining characteristic of American science agencies. Both American scientists and the public must consider whether it is in either party's best interest to provide scientists with such broad-ranging independence. The American public has voluntarily supported science funding for decades through their elected representatives but has had little to no voice in what research is funded. The negative impacts of excluding citizens and underrepresented groups from influencing the direction of science have been severe. According to the Pew Research Center, Black Americans are 14\% less likely to have confidence in scientists and are more than twice as likely to say that they have not too much or no confidence in scientists to act in the public interest (Funk, Kennedy, and Tyson 2020). Providing Black Americans and other underrepresented groups a seat at the table in U.S. science agencies could be a first step toward promoting equity and furthering trust in science.

As scientists, it is tempting to suggest that including non-expert citizen input would lead to undue influence by interest groups. Those with the mindset of Dr. Bush, known for his idea that merit is the proper way to distribute funding, may even assert that the quality of research would be diminished by incorporating citizen input. These tired arguments against citizen input present a false dichotomy between scientific independence or total citizen control. In reality, a power sharing arrangement between scientists and non-expert citizens is possible. Unfortunately, this false dichotomy has mistakenly perpetuated Dr. Bush's misguided and elitist view of science. More importantly, this argument has perpetuated the idea that influence by citizens with their own interests is somehow bad for science. Passionate citizens who know about the issues facing their communities could help guide research to address these issues while scientists could ensure that researchers are still able to pursue their curiosity. Experts certainly have their place reviewing jargon-filled research proposals, where technical knowledge is needed to determine the scientific merit of the proposed work. We believe, however, that both science and the public would benefit from having non-experts help shape the overall direction of research and the operations of U.S. science agencies.

The rejection of democratic principles, mistrust of science, and inequity that result from excluding citizen input all illustrate the need to give full consideration to Senator Kilgore's vision for greater public accountability in federally funded research. We assert that providing a seat at the table for nonexperts would help to ensure that science progresses in a manner that better understands and addresses the needs of the public, while also ensuring that scientific rigor is not diminished. Diverse perspectives within businesses and even within research groups are known to correlate with improved performance (Lorenzo et al. 2018; AlShebli et al. 2018). Including a diverse cross section of citizens, such as community leaders, teachers, 
representatives of the workforce, and members of groups historically underrepresented in the sciences, should therefore boost the performance of each relevant science agency. Scientists also already recognize the value of using different perspectives to provide accountability and transparency in the research process. The peer review system can be found ubiquitously throughout the sciences, a prerequisite to publish findings in any reputable journal. Additionally, interdisciplinary research collaborations are becoming more relevant to the modern world and have more staying power, earning more citations over a longer period of time than noncollaborative ventures (Van Noorden 2015). This shows that scientists can often provide a beneficial perspective when undertaking cross-disciplinary work, even if they lack expertise in a particular field. We believe that the unique perspective of non-expert citizens would provide a similar benefit to U.S. science agencies. We propose that U.S. science agencies integrate members of the public into their advisory boards to help better shape the direction of American research and increase the equitability of science.

\section{A pathway to including citizen input}

A potential method for selecting relevant non-expert advisory board members for each agency could be through the previously appointed experts themselves. With the power to appoint non-expert citizens, these expert board members can retain their deserved influence without sacrificing public representation. Specifically, this approach to selection should assuage the fears of scientists and researchers, as expert board members would be able to ensure that they choose citizens who have the best interest of the scientific agency in mind. For example, community leaders, teachers, and representatives of the workforce would be excellent candidates for expert board members to appoint. We believe these appointed citizens should be provided with equal power to their expert counterparts and also serve the same terms. In this structure, experts would be able to retain their deserved influence. With such a powersharing structure, they would also be able to prevent citizen input that goes against scientific principles. Additionally, this would allow citizens to bring their diverse perspectives and knowledge about the needs of the public to the table, increase overall productivity, and help make science more equitable.
Successful collaborations between citizens and scientists already exist on a smaller scale. The Department of Defense currently funds a Breast Cancer Research Program, where researchers work directly with breast cancer survivors to fund new and innovative approaches to fight the deadly disease (Congressionally Directed Medical Research Programs 2020, 2). This effort has already found considerable success; the program has funded research behind several approved therapeutics (Congressionally Directed Medical Research Programs 2020,14). Agencies can also look internally for guidance on integrating non-expert opinions. The NIH's Center for Advancing Translational Sciences' Strategic Plan specifically recognizes the need for increased engagement with non-experts in translational research. The plan highlights that "engagement of patients and their communities throughout the lifecycle of a translational research project ensures the outcomes are relevant to and directly address patient needs and will be more readily adopted by the community" (National Center for Advancing Translational Sciences 2017). Another example of citizen input already embedded in U.S. science agencies is the six-member working group of scientists and two representatives from the Lacks family at the NIH. This group reviews applications for full access to the genome of HeLa cells-a cell line containing sensitive DNA information about the Lacks family, derived from a tumor taken from Henrietta Lacks in 1951 without her consent (National Institutes of Health 2013). In these examples, sharing power between citizens and scientists has filled the mutually destructive gap created by excluding citizens from important decisions. In order to remedy the disconnect between scientists and non-experts that currently exists in the leadership of U.S. science agencies, we believe that members of the public should have some mechanism to help direct research to meet their needs.

\section{A call to action}

Legislation is currently working its way through Congress that represents bold and necessary change to several U.S. science agencies. Although the proposed bills would transform U.S. science, an essential change is still missing: including a mechanism for citizen input. We believe that Congress must do the following to remedy the lack of citizen input that defines these agencies: 
- Legislate the creation of National Science Board-style advisory boards, with the power to manage research activities in conjunction with their agency director, in nondefense science agencies including the National Institutes of Health, Department of Energy, Department of Agriculture, National Aeronautics and Space Administration, National Institutes of Standards and Technology, National Oceanic and Atmospheric Administration, and Department of Transportation.

- Empower these advisory boards to, with respect to each agency's research activities, identify issues that are critical to the agency's future, approve the agency's strategic budget directions and the annual budget submission to the Office of Management and Budget, and approve new major programs and awards.

- Mandate that each Presidentially appointed expert board member appoint a non-expert colleague with equal power, such as a community leader, teacher, representative of the workforce, or member of a group historically underrepresented in the sciences.

- Require that non-expert citizen board members represent the diversity of the United States.

We urge legislators to adopt these plans to include diverse citizen input in all U.S. science agencies. This will improve the performance of the agencies and will also send a strong signal to reassure the publicespecially those currently underrepresented in the sciences-that researchers care about the interests and needs of the American people. With inclusive modifications based on the ideas originally set forth by Senator Harley Kilgore after WWII, America's science agencies can begin to more effectively and equitably reap the rewards of science.

General Services Administration. "GSA Federal Advisory Committee Act (FACA) Database." Accessed July 9, 2021.

https://www.facadatabase.gov/FACA/FACAPubli cAgencyNavigation.

Kevles, D. J. 1974. "FDR's Science Policy." Science 183

Bush, Vannevar. 1945. "Science, The Endless Frontier." United States Government Printing Office. https://www.nsf.gov/od/lpa/nsf50/vbush1945. htm

Congressionally Directed Medical Research Programs. 2020. "Breast Cancer Research Program." Accessed March 28, 2021.

https://cdmrp.army.mil/bcrp/pbks/bcrppbk202 1.pdf

England, J. Merton. 1976. "Dr. Bush Writes a Report: 'Science, The Endless Frontier."' Science 191 (4222): 41-47. https://www.jstor.org/stable/1741846

Funk, Cary, Brian Kennedy, and Alec Tyson. 2020. "Black Americans Have Less Confidence in Scientists to Act in the Public Interest." Pew Research Center (blog). August 28, 2020. https://www.pewresearch.org/facttank/2020/08/28/black-americans-have-lessconfidence-in-scientists-to-act-in-the-publicinterest/.
Lorenzo, Rocío, Nicole Voigt, Miki Tsusaka, Matt Krentz, and Katie Abouzahr. 2018. "How Diverse Leadership Teams Boost Innovation." BCG Henderson Institute. January 23, 2018.

https://www.bcg.com/enus/publications/2018/how-diverse-leadershipteams-boost-innovation.

National Center for Advancing Translational Sciences. 2017. "Strategic Goal 2: Fostering Innovative Partnerships." Accessed March 28, 2021. https://ncats.nih.gov/strategicplan/goal2

National Institutes of Health. 2019. "Charter of the NIH Advisory Committee to the Director." Accessed July 9, 2021. https://www.acd.od.nih.gov/charter.html

National Institutes of Health. 2013. "NIH, Lacks Family Reach Understanding to Share Genomic Data of HeLa Cells." National Institutes of Health. https://www.nih.gov/news-events/newsreleases/nih-lacks-family-reach-understandingshare-genomic-data-hela-cells.

\section{(4127): 798-800.
http://doi.org/10.1126/science.183.4127.798-b. \\ (4127): 798-800.
http://doi.org/10.1126/science.183.4127.798-b.}


National Institutes of Health. 2021. "Council of Councils." Accessed July 9, 2021. https://dpcpsi.nih.gov/council.

National Science Foundation. n.d. "About the NSB." National Science Foundation. Accessed March 28, 2021. http://www.nsf.gov/nsb.

Neal, Homer A., Tobin L. Smith, and Jennifer B. McCormick. 2008. Beyond Sputnik: U.S. Science Policy in the Twenty-First Century. Ann Arbor: University of Michigan Press. https://doi.org/10.3998/mpub.22958

President Truman, speaking on S. 526, on August 6, 1947, 80th Cong., 1st sess., Congressional Record 93, pt. 8.
Slaoui, Moncef, and Matthew Hepburn. 2020. "Developing Safe and Effective Covid Vaccines - Operation Warp Speed's Strategy and Approach." New England Journal of Medicine 383 (18): 1701-3. https://doi.org/10.1056/NEJMp2027405.

U.S. Department of Agriculture. 2019. "History of Research at the U.S. Department of Agriculture and Agricultural Research Service." U.S. Department of Agriculture. Accessed March 28, 2021. https://www.ars.usda.gov/oc/timeline/comp/

Van Noorden, Richard. 2015. "Interdisciplinary Research by the Numbers." Nature 525 (7569): 306-7. https://doi.org/10.1038/525306a.

Zachary, G. Pascal. 1997. Endless Frontier: Vannevar Bush, Engineer of the American Century. New York: Free Press.

Patrick Buckley is currently a student in the DiMaio Laboratory at Yale University where he is pursuing a Ph.D. in microbiology. In his research, Patrick uses biochemical and cellular assays to study the activity of the papillomavirus cell-penetrating peptide sequence to understand its importance in infection and its potential as a research tool and therapeutic delivery device. He is a recipient of the National Science Foundation Graduate Research Fellowship and serves as a submissions editor for the Yale Journal of Health Policy, Law, and Ethics. Previously, Patrick graduated from SUNY Geneseo in Western New York with a B.S. in biochemistry.

Kristen Ramsey is currently a student in the Kazmierczak Laboratory at Yale University where she is pursuing a Ph.D. in microbiology. Kristen uses microscopy and genetic techniques in her research on Pseudomonas aeruginosa bacteria to determine the factors that contribute to phenotypic differences within genetically identical populations. At Yale, Kristen is the secretary for the Yale Student Science Diplomats science policy advocacy group and a mentor for those underrepresented in STEM with the Yale Biological and Biomedical Sciences Diversity and Inclusion Collective. Previously, Kristen graduated from the University of Maryland with a B.S. in general biology.

\section{Acknowledgements}

We would like to thank Dana Hayward and Adam Fofana for their helpful comments on this article. 